\title{
OCENNY CHARAKTER ZNAMION PRZESTĘPSTW NARKOTYKOWYCH
}

Zgodnie z gwarancyjną funkcją prawa karnego i kluczową dla niej zasada nullum crimen sine lege, zachowania, które ustawodawca uznał za społecznie szkodliwe i które winny zostać stypizowane w ustawie karnej jako czyny zabronione, muszą zostać w niej jasno określone. Określenia tego dokonuje sie przez skonstruowanie opisu czynu za pomoca jego znamion ${ }^{1}$. Pochylenie się nad problematyką znamion czynu zabronionego w ogóle oraz nad ich rozmaitymi ujęciami wykraczałoby poza ramy niniejszego artykułu², którego tematem mają być znamiona ocenne. Zgodzić się zresztą należy ze Zbigniewem Jędrzejewskim, że znaczenie wyrażanej przez znamiona Tatbestand - istoty czynu czy też jego określoności, zależy od przypisywanej tym pojęciom funkcji ${ }^{3}$. Dla przykładu można tu przytoczyć chociażby ujęcie Tatbestand zaproponowane przez Clausa Roxina. Ze względu na systematyczna, kryminalnopolityczną i dogmatyczną funkcję zespołu znamion wyodrębnia on systemowy zespół znamion (Systemtatbestand), zespół gwarancyjny (Garantietatbesand) i zespół znamion związanych z konstrukcją błędu (Irrtumstatbestand) ${ }^{4}$. Na potrzeby rozważań będących przedmiotem niniejszego artykułu, nieco upraszczając, przyjąc można, że ustawowe znamiona przestępstwa stanowią po prostu zarys typu czynu zabronionego ${ }^{5}$.

Zwrócić trzeba uwagę na funkcje, które w założeniu maja pełnić znamiona czynu zabronionego. Kluczowa jest funkcja selekcyjna zespołu znamion, pozwalająca na odróżnienie czynów zabronionych od czynów prawnokarnie irrelewantnych ${ }^{6}$. Funkcja indywidualizująca znamion wyraża się natomiast

\footnotetext{
${ }^{1}$ Zob. W. Wolter, Nauka o przestepstwie, Warszawa 1973, s. 40; por. A. Zoll, Okoliczności wytaczajace bezprawność czynu (zagadnienia ogólne), Warszawa 1982, s. 26 i T. Bojarski, Odmiany podstawowych typów przestęstw w polskim prawie karnym, Lublin 1979, s. 5.

${ }^{2}$ Kształtowanie się nauki o zespole znamion czynu zabronionego oraz liczne koncepcje tych znamion zostały w polskiej nauce prawa karnego kompleksowo opisane przez R. Dębskiego - zob. idem, Typ czynu zabronionego (typizacja), w: R. Dębski (red.), Nauka o przestępstwie. Zasady odpowiedzialności, System prawa karnego, t. 3, Warszawa 2013, s. 354-377.

${ }^{3}$ Zob. Z. Jędrzejewski, Bezprawność jako element przestępności czynu. Studium na temat struktury przestepstwa, Warszawa 2009, s. 215.

${ }^{4}$ Zob. R. Dębski, op. cit., s. 376.

${ }^{5}$ Zob. I. Andrejew, Ustawowe znamiona czynu: typizacja i kwalifikacja przestepstw, Warszawa 1978 , s. 71.

${ }^{6}$ Zob. idem, Ustawowe znamiona przestepstwa, Warszawa 1959, s. 7 i R. Dębski, Pozaustawowe znamiona przestepstwa: o ustawowym charakterze norm prawa karnego $i$ znamionach typu czynu zabronionego nie określonych w ustawie, Łódź 1995, s. 99.
} 
w możliwości odróżnienia poszczególnych typów czynów zabronionych. Z funkcji selekcyjnej i indywidualizującej wynikają nadto funkcje ostrzegawcza i informacyjna, wskazujące, które zachowania są czynami zabronionymi pod groźba kary ${ }^{7}$. Funkcje te najściślej związane sa z zasada nullum crimen sine lege ${ }^{8}$ i pełnią zasadniczą rolę dla adresatów norm prawnokarnych, wśród których są także, a może przede wszystkim, zwykli obywatele. Zgodzić się bowiem należy z Lechem Gardockim, że „Najważniejszą funkcją zasady nullum crimen sine lege jest danie obywatelom możliwości zorientowania się, za jaki czyn grozi im odpowiedzialność karna"9.

Istotny jest także powszechnie wyróżniany w polskiej nauce prawa karnego podział logiczny znamion na znamiona opisowe, zwane też deskryptywnymi, i znamiona ocenne ${ }^{10}$, których istota stanowi przedmiot niniejszego artykułu. Celowe jest zatem bliższe pochylenie się nad charakterem i dyferencjacją znamion opisowych i ocennych.

Znamionom opisowym przypisuje się przymiot precyzyjności w opisie zarysu typu czynu zabronionego. Postrzega się je przy tym jako obiektywnie sprawdzalne ${ }^{11}$, a co za tym idzie, dodatnio wpływające na pewność i równość obywateli wobec prawa. W wypadku typizacji dokonanej wyłącznie za pomoca znamion opisowych, sąd, lub jakikolwiek inny organ stosujący prawo, musi jedynie dokonać prostej subsumcji danego stanu faktycznego pod dany typ czynu zabronionego. Nie jest potrzebna zatem żadna ocena tych znamion ${ }^{12}$. Przykładem znamion deskryptywnych mogą być takie znamiona, jak: „rzecz”, „zabijać”, „człowiek”. Znamiona ocenne, zwane też wartościującymi, nie mogą zostać rozpoznane w konkretnym czynie poprzez zwykła subsumcję, ale wymagają już, jak sama nazwa wskazuje, pewnej oceny - procesu wartościowania. Jako przykład można tu wskazać znamię „szczególnego okrucieństwa” pojawiające się m.in. w art. $197 \S 4$ k.k. i ,istotna informację", o której mowa w art. 268 k.k., ale też cały szereg tzw. znamion ilościowych - np. ciężki uszczerbek czy długotrwała choroba, o których mowa w art. $156 \S 1$ k.k. Na podział znamion na opisowe i ocenne nakłada się podział na znamiona ostre i nieostre. Znamiona ostre tworzą wyraźny zarys czynu zabronionego, znamiona nieostre czynią zarys ten niewyraźnym ${ }^{13}$. Inaczej mówiąc, znamiona ostre wyraźnie zarysowują zbiór desygnatów danego typu czynu zabronionego, znamiona nieostre użyte w typizacji sprawiają natomiast, że zbiór ten jest niejednoznaczny. Słusznie zauważa Władysław Wolter, że znamiona nieostre stają się znamionami ocennymi

\footnotetext{
${ }^{7}$ R. Dębski, Typ..., s. 383.

${ }^{8}$ Niektórzy autorzy wyróżniają odrębną funkcję gwarancyjną zespołu znamion - zob. m.in. T. Bojarski, op. cit., s. 10.

${ }^{9}$ L. Gardocki, Typowe zakłócenia funkcji zasady nullum crimen sine lege, „Studia Iuridica” 1982 , nr 10, s. 35.

${ }^{10}$ Zob. m.in. ibidem, s. 37; T. Bojarski, op. cit., s. 12 i I. Andrejew, Zagadnienia typizacji przestepstw, „Studia Iuridica” 1982, nr 10, s. 15.

${ }^{11}$ Zob. I. Andrejew, Ustawowe..., s. 109.

${ }^{12}$ Zob. R. Dębski, Typ..., s. 393. T. Bojarski o znamionach opisowych pisał: „Przez znamiona opisowe rozumiemy takie, które nawiązują do faktów empirycznie sprawdzalnych, do faktów które możemy obserwować, ustalić z mniejszą lub większą dokładnością" - idem, op. cit., s. 12.

${ }^{13}$ Zob. I. Andrejew, Ustawowe..., s. 111.
} 
i w konsekwencji „ocena musi dokonać tego, czego nie uczynił opis ${ }^{14 ”}$. Ostrość znamienia ocennego można uzyskać poprzez posłużenie się liczebnikami w jego ustawowej precyzacji. W obecnie obowiąującym Kodeksie karnym ustawodawca wprost wskazuje w art. $115 \S 5$ k.k., że znamię „mienie znacznej wartości”, pojawiające się np. w typizacji czynu zabronionego z art. $167 \S 1$ k.k., oznaczana mienie, którego wartość w czasie popełnienia czynu przekracza $200000 \mathrm{zł}$. Podobnie w art. $115 \S 10 \mathrm{k} . k$. ustawodawca formułuje definicję legalną młodocianego, o którym wspomina m.in. $54 \S 1$ k.k. W definicji tej wskazuje się dokładnie granicę wieku sprawcy, który może zostać uznany za młodocianego. Takie przydanie ostrości znamionom ocennym i czynienie z nich w ten sposób właściwie znamion opisowych może budzić pewne wątpliwości. Warto bowiem zwrócić uwage na tzw. wypadki graniczne ${ }^{15}$. Przykładowo, za młodocianego zostanie uznany sprawca, który dopuścił się czynu zabronionego dzień przed swoimi dwudziestymi pierwszymi urodzinami, ale już nie sprawca, który dopuścił się czynu dzień po urodzinach ${ }^{16}$. Sztuczność takiego rozwiązania jest aż nazbyt wyraźna. Zgodzić się jednak trzeba z W. Wolterem, iż jest to swego rodzaju zapłata właśnie za uzyskaną ostrość ${ }^{17}$. Poza tym wypadki graniczne w praktyce stosowania prawa pojawiają się niezwykle rzadko.

Dla pełnego nakreślenia problematyki znamion ocennych i nieostrych warto przytoczyć jeszcze rozważania Macieja Zielińskiego co do niedookreśloności i nieostrości zwrotów użytych w ustawie. Autor ten wskazuje, że niedookreśloność i nieostrość są właściwościami zwrotów językowych ${ }^{18}$. Niedookreślność dotyczy znaczenia danego zwrotu, nieostrość zaś - jego zakresu. Każdorazowo niedookoreślność, która ma charakter językowy, pociaga za sobą nieostrość mającą charakter logiczny ${ }^{19}$. W przypadku nieostrości danej nazwy nie można jednoznacznie orzec, czy dany przedmiot jest jej desygnatem czy też nie - czy wchodzi do jej zakresu czy nie. M. Zieliński wskazuje na istnienie przy każdym zwrocie nieostrym tzw. pasa nieostrości - w jego zakresie mieszczą się te przedmioty, co do których ciężko zdecydować, czy wchodzą w zakres danej nazwy ${ }^{20}$. Prowadzi to do powstania tzw. luzów decyzyjnych podmiotów stosujacych prawo.

Nieodparcie nasuwa się więc pytanie, czy ustawodawca, typizując w Kodeksie karnym i w innych ustawach poszczególne czyny zabronione za pomocą znamion ocennych i nieostrych, uczynił to celowo - tzn. chcac pozostawić sądowi właśnie pewien zakres luzu decyzyjnego, czy też nieostre typy przestępstw są niepożądaną i problematyczną koniecznością. Jeśli zaś odpowiedź na pierwszy człon pytania miałaby być twierdząca, to powstaje kolejne pytanie

${ }^{14}$ W. Wolter, op. cit., s. 94.

15 Zob. I. Andrejew, Ustawowe..., s. 112-113.

16 Por. ibidem, s. 225.

17 W. Wolter, op. cit., s. 94.

18 Zob. M. Zieliński, Wykładnia prawa. Zasady, reguty, wskazówki, Warszawa 2010, s. 172.

19 Zob. ibidem, s. 172-174.

${ }^{20}$ Zob. ibidem, s. 176. Jako przykład nazwy nieostrej i jej pasa nieostrości M. Zieliński podaje nazwę „wysoki mężczyzna”, wskazując, że pas nieostrości występuje tu prawdopodobnie w przedziale 177-182 cm. Nie wiadomo mianowicie, czy mężczyznę o takim wzroście możemy już uznać za wysokiego. Wątpliwość taka znika powyżej wzrostu $182 \mathrm{~cm}$. 
o zakres tego luzu, o to, jak daleko może on sięgać - jak szeroki może być pas nieostrości danego typu.

M. Zieliński wskazuje, że posługiwanie się zwrotami nieostrymi należałoby uznać za zamierzone przez ustawodawcę, który „poruszając się między Scyllą precyzji a Charybdą elastyczności wybrał elastyczność” ${ }^{21}$, chcąc by sąd, znając konkretny stan faktyczny, zadecydował wedle swego najlepszego rozeznania o jego subsumpcji pod daną typizacje $e^{22}$. Igor Andrejew stwierdza natomiast, że przekształcenie znamion ocennych w opisowe nie byłoby łatwe i prowadziłoby do powstania długich, kazuistycznych opisów danych typów ${ }^{23}$.

Zgodzić się z pewnością należy, że niemożliwe jest skonstruowanie ustawowego opisu wszystkich typów czynów zabronionych wyłącznie za pomoca znamion deskryptywnych i ostrych ${ }^{24}$. Jednocześnie też trzeba jednak podkreślić, że: „O ustawodawcy zakłada się między innymi i to, że nie zamierza on do siania zamętu, a w związku z tym i to, że stara się formułować stanowione przez siebie normy w przeważającej większości w sposób możliwie najbardziej jednoznaczny i precyzyjny" "25, co ściśle wiąże się z poczuciem pewności prawa. Wskazuje się nadto, że znamiona opisowe zdecydowanie lepiej spełniaja gwarancyjną funkcję prawa karnego niż znamiona ocenne i nieostre ${ }^{26}$.

Zasadę nullum crimen sine lege wyrażająca funkcję gwarancyjną prawa karnego, w jej precyzacji nullum crimen sine lege certa, należy rozumieć jako postulat czy wręcz nakaz określoności czynów zabronionych ${ }^{27}$. Typ przestępstwa tym lepiej spełnia wszystkie przypisywane mu funkcje, im lepiej jest określony $^{28}$. Samo posłużenie się w typizacji znamionami ocennymi i nieostrymi zasady tej jeszcze nie narusza. Zbyt duży pas nieostrości i tym samym zbyt duży luz decyzyjny może już jednak prowadzić do nadmiernego wzrostu roli wykładni i zaistnienia de facto aktu quasi-prawotwórczego po stronie władzy sądowniczej ${ }^{29}$. Decyzja, czy dane zachowanie jest czynem zabronionym, będzie bowiem w większym stopniu zależna od sędziowskiego uznania niż od słów ustawy, dodajmy, słów nieostrych i nieprecyzyjnych. Zgodzić trzeba się z Tadeuszem Bojarskim, że im gorsza (w znaczeniu mniej precyzyjna) typizacja, tym większa rola organów stosujących prawo i tym słabsza pozycja obywatela, który pozostaje w niekomfortowej sytuacji braku pewności ${ }^{30}$.

By ocenić, czy posługiwanie się przez ustawodawcę znamionami ocennymi może niekiedy stanowić poważne zagrożenie dla zasady nullum crimen sine lege certa, spójrzmy na konkretne przepisy karne. Za przykład niech posłuża

21 Ibidem, s. 179.

22 Zob. ibidem. Por. Z. Tobor, W poszukiwaniu intencji prawodawcy, Warszawa 2013, s. 208.

${ }^{23}$ Zob. I. Andrejew, Zagadnienia..., s. 25.

${ }_{24}$ Zob. W. Wolter, op. cit., s. 92.

25 M. Zieliński, Wykładnia..., s. 148.

26 Zob. T. Bojarski, op. cit., s. 12.

27 Zob. R. Dębski, Pozaustawowe..., s. 20.

${ }_{28}$ Zob. I. Andrejew, Zagadnienia..., s. 20.

${ }_{29}$ Zob. K. Mamak, Niejasny opis typu czynu zabronionego a zasada nullum crimen sine lege, w: I. Sepioło (red.), Nullum crimen sine lege, Warszawa 2013, s. 67 por. I. Andrejew, Ustawowe..., s. 7.

${ }^{30}$ T. Bojarski, op. cit., s. 14; por. K. Mamak, op. cit., s. 61; T. Kozioł, Znaczna ilość środka odurzajacego, „Prokuratura i Prawo” 2010, nr 11, s. 62. 
przepisy ustawy o przeciwdziałaniu narkomanii ${ }^{31}$. W szeregu przepisów tej ustawy pojawia się znamię „znacznej ilości” odnoszace się do środków odurzających. Za pomoca tego znamienia wyodrębniono typy kwalifikowane przestępstw polegajacych na nielegalnym wytwarzaniu (art. 55 ustawy), wprowadzaniu do obrotu (art. 56 ustawy), udzielaniu, ułatwianiu, umożliwianiu lub nakłanianiu do użycia (art. 58 ustawy), nielegalnym posiadaniu (art. 62 ustawy), nielegalnej uprawie (art. 63 ustawy) i kradzieży środków odurzajacych (art. 64 ustawy). W art. 62a ustawy przewidziano natomiast możliwość umorzenia postępowania w sytuacji, gdy sprawca nielegalnie posiadał środki odurzające w ilości nieznacznej i były one przeznaczone na jego własny użytek. Odpowiedzialność sprawcy za różne czyny związane ze środkami odurzającymi uzależniona jest więc niejednokrotnie od tego, czy ilość środków, których dotyczył czyn, była „znaczna”.

Oczywiście od razu nasuwa się pytanie, co ustawodawca rozumie przez nieostre i tym samym ocenne znamię „znacznej ilości” środków odurzajacych. W ustawie próżno szukać definicji legalnej tego znamienia. Ustalenie jego znaczenia pozostawiono więc doktrynie i orzecznictwu. Przegląd stanowisk w tym zakresie ujawnia jednak ogromne rozbieżności zapatrywań. Formułowany jest m.in. pogląd, że ocena, co do „znaczności” ilości środków odurzających powinna być dokonywana na podstawie kryteriów jakościowych i ilościowych, mianowicie - gramatury danej ilości środka, rodzaju tegoż środka (w zależności od tego, czy jest to tzw. narkotyk „twardy” czy „miękki”), a także celu jego przeznaczenia ${ }^{32}$.

Nieco odmienny pogląd wskazuje, że o „znaczności” decyduje wagowa ilość danego środka odniesiona do potrzeb jednej osoby uzależnionej ${ }^{33}$. Rozbieżność, co do liczby osób, które ma zaspokoić „znaczna ilość” narkotyku, jest przy tym bardzo duża. Są Apelacyjny w Krakowie w orzeczeniu z 24 lipca 1997 r. wprost wskazał, że znaczna ilość narkotyku „[...] to taka ilość, która wystarczy do jednorazowego odurzenia się najmniej kilkudziesięciu osób”34. Natomiast w uzasadnieniu innego wyroku tegoż Sądu czytamy, że „[...] znaczna ilość narkotyku to ilość, która wystarcza do jednorazowego odurzenia kilku tysięcy osób" 35.

Nie brakuje też judykatów ograniczających ocenę kwestii, czy dana ilość środków odurzających była „znaczna” jedynie do kryterium ilościowego, niezależnie od typu narkotyku i jego docelowego przeznaczenia ${ }^{36}$. Przy czym dolna

${ }^{31}$ Ustawa z 29 lipca 2005 r. o przeciwdziałaniu narkomanii, t.jedn.: 10 stycznia 2012 r., Dz. U. 2012, poz. 124.

${ }^{32}$ Zob. wyrok SA w Warszawie z 18 kwietnia 2000 r., II AKa 22/00, OSA 2001, nr 2, poz. 8 oraz wyrok SA we Wrocławiu z 30 maja 2003 r., II AKa 167/03, OSA 2003, nr 9, poz. 92.

${ }^{33}$ Zob. T. Srogosz, Ustawa o przeciwdziataniu narkomanii. Komentarz, Warszawa 2008, s. 372 i wyrok SA w Lublinie z 17 grudnia 2002 r., II AKa 282/02, OSA 2003, nr 9, poz. 94.

${ }^{34}$ Wyrok SA w Krakowie z 24 lipca 1997 r., II AKa 94/97, „Prokuratura i Prawo” 1998, nr 5, poz. 20.

${ }^{35}$ Wyrok SA w Krakowie z 26 czerwca 2012 r., II AKa 92/12, Lex, nr 1227661.

${ }^{36}$ Zob. m.in. wyrok SN z 17 czerwca 1999 r., IV KKN 813/98, „Prokuratura i Prawo” 2000, nr 1, poz. 2 i wyrok SA w Krakowie z 8 listopada 2013 r., II AKa 220/13, Lex, nr 1466287. 
granica „znacznej ilości” w orzecznictwie oscyluje w przedziale od kilku gramów do kilkudziesięciu kilogramów ${ }^{37}$.

Dość ważki problem stanowi również posłużenie się znamieniem „znacznej ilości" przy bardzo różnych typach przestępstw narkotykowych. Znamię to pojawia się bowiem zarówno w typie kwalifikowanym penalizującym wprowadzanie do obrotu znacznej ilości narkotyków oraz w typie kwalifikowanym penalizującym udzielanie znacznej ilości narkotyków. Oczywiste jest, że zazwyczaj wprowadzane do obrotu sa ilości „hurtowe” środków odurzających, natomiast ich ilość udzielana przez jedną osobę drugiej jest zazwyczaj znacznie mniejsza. Stąd też wskazuje się, że „inną granicę znacznej ilości należy przyjąć w przypadku czynów polegajacych na udzieleniu środka odurzającego lub substancji psychotropowej, kiedy to taki środek czy substancja trafia bezpośrednio do osoby je używającej, a inna w przypadku wprowadzenia tych środków lub substancji do obrotu lub uczestniczenia w takim obrocie" ${ }^{38}$. Zauważyć jednak trzeba, że pogląd taki kłóci się z założeniem o racjonalności prawodawcy. $\mathrm{Z}$ założenia tego wyprowadza się bowiem regułę interpretacyjna, zgodnie $\mathrm{z}$ która dane słowo lub zwrot językowy powtarzajacy się w tekście prawnym ma zawsze to samo znaczenie ${ }^{39}$. Zgodnie z tą reguła znamię „znacznej ilości” pojawiajace się w ustawie o przeciwdziałaniu narkomanii należałoby każdorazowo rozumieć tak samo.

Próby przełamania założenia o racjonalności prawodawcy oraz ukazana wyżej rozpiętość ocen dotyczących znamienia „znacznej ilości”, bez względu na przyjęte kryteria, oznaczaja, że pas nieostrości przy typach czynów zabronionych, w których posłużono się znamieniem „znacznej ilości” jest niezwykle szeroki, a tym samym luz decyzyjny sąów jest właściwie nieograniczony. Widać to też bardzo wyraźnie po przytoczonym wyżej orzecznictwie. Nasuwa się więc w pełni uzasadniona konstatacja, że zasada nullum crimen sine lege certa i gwarancyjna funkcja prawa karnego doznają uszczerbku ze względu na funkcjonowanie takich przepisów, jak te zawarte w ustawie o przeciwdziałaniu narkomanii.

Gdyby nawet przejść nad tym faktem do porządku dziennego i stwierdzić, że jest to cena elastyczności pozostawionej organom stosujaccym prawo i alternatywa dla ostrego liczbowego określania znacznej ilości, to pozostaja jeszcze niezwykle ważkie kwestie związane ze znamionami strony podmiotowej danych czynów zabronionych.

Od dziesięcioleci wskazuje się w nauce prawa karnego, że aby mówić o umyślności po stronie sprawcy czynu zabronionego, konieczne jest odbicie się w jego świadomości desygnatów wszystkich przedmiotowych znamion danego czynu zabronionego ${ }^{40}$. Aby więc uznać kogoś za sprawcę czynu zabronionego polegającego np. na posiadaniu znacznej ilości środków odurzających, tj. czynu

${ }^{37}$ Zob. m.in. wyrok SA w Katowicach z 6 listopada 2003 r., II AKa 56/03, „Prokuratura i Prawo" 2004 , nr 11-12, poz. 32 .

${ }^{38}$ Wyrok SA w Katowicach z 12 listopada 2005 r., II AKa 282/05, Lex, nr 183871.

${ }^{39}$ Zob. Z. Ziembiński, w: S. Wronkowska, Z. Ziembiński (red.), Zarys teorii prawa, Poznań 1997, s. 166.

${ }^{40}$ Zob. I. Andrejew, Ustawowe..., s. 21 i W. Wróbel, A. Zoll, Polskie prawo karne. Część ogólna, Kraków 2010, s. 207. 
z art. 62 ust. 2 ustawy o przeciwdziałaniu narkomanii ${ }^{41}$, należałoby udowodnić w toku procesu karnego, że sprawca swoją świadomością obejmował fakt, że ilość narkotyków, które posiada jest znaczna. Od razu nasuwa się pytanie, jak sprawca ma ocenić, czy ilość ta jest znaczna, i jak, jeśli w ogóle, można udowodnić, że sprawca ową znaczność ilości sobie uświadamiał. Odpowiedzi na te pytania trudno udzielić.

Pamiętać należy, że ustawowy zestaw znamion pełni też funkcję dowodowa. Oznacza to, że fakt realizacji przez sprawcę wszystkich znamion czynu, także tych podmiotowych, musi być wykazany w procesie karnym ${ }^{42}$. Zgodzić trzeba się z I. Andrejewem, że sąd jest zobligowany do dokonania w toku procesu karnego podwójnej subsumcji ${ }^{43}$. Musi, po pierwsze, rozpoznać w danym czynie znamiona strony przedmiotowej przestępstwa, a następnie stwierdzić, czy znamiona te znalazły odbicie w świadomości sprawcy ${ }^{44}$. Kolejność ta nie jest przypadkowa. Strona podmiotowa musi być bowiem odnoszona do kompletu znamion przedmiotowych czynu ${ }^{45}$.

Jeśli więc nawet sąd poradzi sobie z wykładnią ocennego znamienia „znacznej ilości”, to pozostaje przed nim jeszcze niezwykle trudne zadanie wykazania, że sprawca ową znaczną ilość obejmował swym zamiarem, a dokładniej mówiąc - swą świadomością. Automatyczne przyjęcie, że tak było, z oczywistych względów kłóci się z zasadą subiektywizmu prawa karnego. Posługiwanie się znamionami wybitnie nieostrymi i ocennymi nadwyręża więc nie tylko gwarancyjną funkcję prawa karnego, ale również jego subiektywizm.

Podsumowując powyższe rozważania i ustosunkowując się do pytania postawionego w tytule artykułu, podkreślić trzeba, że z pewnością teksty ustaw niejednokrotnie po prostu muszą być elastyczne ${ }^{46}$. W przypadku przepisów karnych elastyczność ta nie może jednak prowadzić do właściwie niczym nieograniczonej rozpiętości pasa nieostrości i luzu decyzyjnego, tak jak to było w ustawie o przeciwdziałaniu narkomanii. Zgodzić się więc trzeba z Ryszardem Dębskim, że „[...] wobec ustawodawcy sformułować należy postulat unikania stosowania znamion nieostrych w charakterystyce czynów zabronionych" 47 . Znamiona te bowiem nie tylko stają się znamionami ocennymi, ale w konsekwencji prowadzą do zbyt dużej rozbieżności w orzecznictwie. W skrajnych przypadkach, ukazanych w niniejszym artykule na przykładzie przepisów ustawy o przeciwdziałaniu narkomanii, moga zaś być postrzegane jako naruszające gwarancyjną funkcję prawa karnego i zasadę nullum crimen sine lege.

${ }^{41}$ Zgodnie z treścią art. 62 ust. 1 ustawy 1: „kto, wbrew przepisom ustawy, posiada środki odurzające lub substancje psychotropowe, podlega karze pozbawienia wolności do lat 3". Ustęp drugi przedmiotowego przepisu wskazuje zaś, że ,jeżeli przedmiotem czynu, o którym mowa w ust. 1, jest znaczna ilość środków odurzających lub substancji psychotropowych, sprawca podlega karze pozbawienia wolności od roku do lat 10 ”.

42 Zob. I. Andrejew, Ustawowe..., s. 20-21.

${ }^{43}$ Ibidem, s. 21.

44 Ibidem.

45 Zob. Ł. Pohl, Prawo karne. Wykład części ogólnej, Warszawa 2012, s. 146. Konieczne jest zatem uprzednie ustalenie faktów składających się na przedmiotową stronę czynu, by móc sensownie ustalać fakty strony podmiotowej.

${ }^{46}$ Zob. M. Zieliński, Wyktadnia..., s. 178.

47 Zob. R. Dębski, Typ..., s. 405. 
Dowodem na to może być chociażby pytanie prawne skierowane przez jeden z krakowskich sądów rejonowych do Trybunału Konstytucyjnego, dotyczące właśnie zgodności art. 62 ust. 2 i art. 56 ust. 3 ustawy o przeciwdziałaniu narkomanii w zakresie, w jakim przepisy te wprowadzaja niedookreślone znamię „znacznej ilości” z art. 2 w związku z art. 31 ust. 3 Konstytucji. W wyroku wydanym na skutek tak sformułowanego pytania Trybunał stwierdził wprawdzie, że wskazane przepisy ustawy o przeciwdziałaniu narkomanii sa zgodne z Konstytucją ${ }^{48}$, jednakże część argumentów wskazanych w uzasadnieniu wyroku może budzić wątpliwości.

Zgodzić trzeba się ze stwierdzeniem Trybunału Konstytucyjnego, że posłużenie się przez ustawodawcę w tekście ustawy znamionami nieostrymi samo w sobie nie oznacza naruszenia art. 2 Konstytucji i wywodzonej z niego zasady określoności oraz że nie jest możliwe całkowite wyeliminowanie z tekstów ustaw karnych znamion nieostrych i ocennych ${ }^{49}$. Słusznie zauważa także Trybunał, że do ustawy o przeciwdziałaniu narkomanii sformułowano już dwa załączniki zawierające wykaz środków odurzających oraz psychotropowych obejmujący kilkaset pozycji. Przepisy ustawy znajdują zaś zastosowanie do każdej z tych pozycji, wobec czego nie sposób ustalić w tekście ustawy konkretnej „znacznej ilości”, co do każdego wymienionego w załączniku środka odurzajacego lub psychotropowego ${ }^{50}$. Nie przekonuje jednak stanowisko Trybunału zaprezentowane w uzasadnieniu przywołanego wyroku wskazujące, że ocena posłużenia się przez ustawodawcę kryterium ocennym przy konstrukcji typu kwalifikowanego przestępstwa może być łagodniejsza, niż gdyby takie kryterium miało decydować o samej penalizacji zachowania sprawcy ${ }^{51}$. Słusznie zauważa bowiem sędzia Adam Jamróz w uzasadnieniu zdania odrębnego zgłoszonego do wyroku, że w ustawie o przeciwdziałaniu narkomanii typy kwalifikowane przez znamię „znacznej ilości” odróżnia od typów podstawowych jedynie to znamię. Konsekwencją wyodrębnienia typu kwalifikowanego jest przy tym inny, wyższy, wymiar kary zań grożącej. Jeśli więc tylko jedno znamię różnicuje dwa typy przestępstw i decyduje o odmiennych granicach wymiaru kary, to „[...] nie może być niedookreślone w stopniu takim, który umożliwia rozbieżną wykładnię sądów i zasadnicze trudności w zakwalifikowaniu danego stanu faktycznego do jednego z dwu typów przestępstw: podstawowego lub kwalifikowanego" ${ }^{52}$. Miarą wystarczającej określoności i precyzji przepisów, w tym także tych prawnokarnych, jest zaś możliwość ich jednoznacznej wykładni i jednolitego stosowania ${ }^{53}$. Jednolitości w stosowaniu przepisów ustawy o przeciwdziałaniu narkomanii, jak pokazują chociażby przywołane orzeczenia Sądu Najwyższego i sądów apelacyjnego, zdecydowanie jednak brak. Jeśli więc nawet uznać, że posłużenie się przez ustawodawcę w ustawie o przeciwdziałaniu narkomanii nieostrym znamieniem „znacznej ilości” było zabie-

\footnotetext{
${ }^{48}$ Wyrok TK z 14 lutego 2012 r., P 20/10, Dz. U. z 27 lutego 2012 r.

49 Zob. ibidem.

50 Zob. ibidem.

51 Zob. ibidem.

52 Zob. ibidem - zdanie odrębne sędziego A. Jamroza.

53 Zob. ibidem.
} 
giem legislacyjnym w pełni zamierzonym i pozwalającym na prawnokarna regulację całego bogactwa sytuacji, z jakimi sąd może mieć do czynienia, to spoglądając na rozbieżność poglądów orzecznictwa i doktryny co do wykładni tego znamienia czy chociażby na pytanie prawne krakowskiego sądu rejonowego - uznać trzeba, że zabieg ten niezupełnie się udał ${ }^{54}$. Nawiązując do pytania postawionego w tytule niniejszego artykułu, stwierdzić bowiem należy, że elastyczność nieostrego znamienia „znacznej ilości”, zamierzona i być może pożądana przez ustawodawcę, okazała się zbyt problematyczna dla praktyki wymiaru sprawiedliwości.

Nasuwa się więc nieodparcie pytanie o remedium na taki stan rzeczy. Możliwe wydają się dwa rozwiązania. Pierwsze z nich mogłoby polegać na ustawowym zadekretowaniu kryteriów, jakimi miałyby się kierować organy stosujące prawo przy ustaleniu tego, czy daną ilość środków odurzających należy uznać za znaczna. Otwarta pozostaje kwestia, jakie miałyby to być kryteria. Zasadne wydaje się wskazanie na kryterium ilościowe kwalifikowane przez kryterium jakościowe, a więc najpierw należałoby wziąć pod uwagę wagowa ilość danego środka odurzającego, a następnie uwzględnić liczbę porcji o określonym stężeniu, które można z takiej ilości środka uzyskaćs5. Tak określone, mieszane kryteria oceny „znaczności” ilości środka pozwoliłyby zobiektywizować tę ocenę, co w konsekwencji mogłoby się przyczynić do większej jednolitości praktyki orzeczniczej $^{56}$. Zgodzić się przy tym należy z Tomaszem Koziołem, że sama kwestia rodzaju danego środka odurzajacego nie powinna decydować o ocenie znaczności ilości. Uwzględnienie rodzaju środka zawiera się bowiem w kryterium nakazującym uwzględnić ilość porcji ${ }^{57}$.

Ustawowe wskazanie kryteriów mających służyć ocenie tego, czy ilość danego środka odurzającego była znaczna mogłoby pozwolić także na uporanie się, przynajmniej częściowo, z zasygnalizowanym już problemem znamion strony podmiotowej. Łatwiej byłoby bowiem, co do zasady, wykazać, że sprawca swoja świadomością obejmował fakt, że przedmiotem jego czynu jest znaczna ilość środków odurzających w przypadku istnienia ustawowych kryteriów do oceny owej znaczności niż w sytuacji, gdy ocena ta byłaby w pełni arbitralna. Nadto zauważyć trzeba, jak wielokrotnie podkreślano już w nauce prawa karnego, że sprawca nie musi myśleć językiem ustawy. Jego wyobrażenie o ilości środków odurzających, posiadanych, udzielanych czy wprowadzanych do obrotu może zawierać się w myśli o społecznej doniosłości, istotności - wymiarze przedmiotowo pojmowanej społecznej szkodliwości takiej ilości środków odurzających ${ }^{58}$. Tym bardziej że za słuszny należy uznać pogląd, iż: „Utworzenie typów kwalifikowanych przestępstw narkotykowych w oparciu o znamię znacznej ilości środka odurzającego stanowiącego przedmiot czynności wykonawczej, wynika

${ }_{54}$ Por. T. Kozioł, Glosa do wyroku TK z dnia 14 lutego 2012 r., P 20/10, „Państwo i Prawo” 2013, z. 5, s. 136.

${ }_{55}$ Por. P. Gensikowski, Materialnoprawne ujęcie przestanek instytucji przewidzianej $w$ art. $62 a$ ustawy o przeciwdziataniu narkomanii, „Prokuratura i Prawo” 2015, nr 10, s. 103.

${ }^{56}$ Por. wyrok TK z 14 lutego 2012 r., P 20/10, Dz. U. z 27 lutego 2012 r. - zdanie odrębne sędziego A. Jamroza i T. Kozioł, Znaczna..., s. 68.

${ }^{57}$ Ibidem.

${ }^{58}$ Por. I. Andrejew, Ustawowe znamiona czynu..., s. 224. 
z postrzegania ilości środka jako istotnego elementu charakteryzującego społeczną szkodliwość czynów tego rodzaju"59.

Drugim rozwiązaniem obecnie istniejacego problemu z wykładnią znamienia „znacznej ilości” mogłaby być po prostu rezygnacja z wyodrębniania w ustawie o przeciwdziałaniu narkomanii typów kwalifikowanych przez to znamię. Rozwiąanie takie zostało przyjęte w ustawach antynarkotykowych niektórych innych państw - np. Francji i Szwecji. Ilość środka odurzającego będącego przedmiotom danego czynu zabronionego mogłaby wówczas zostać uwzględniona przy wymiarze kary, przy czym granice tego zakresu mogłyby być odpowiednio szersze.

Pierwsze ze wskazanych wyżej rozwiąań, tj. wprowadzenie ustawowych kryteriów oceny tego, czy ilość środka odurzającego była znaczna, postrzegam jako lepsze. Przede wszystkim wiązałoby się ono z mniejszą ingerencją w obowiązujący kształt przepisów ustawy o przeciwdziałaniu narkomanii. Nadto drugiemu ze wskazanych rozwiązań - rezygnacji z wyodrębniania typów kwalifikowanych przez znamię „znacznej ilości” zarzucić można brak rzeczywistej likwidacji problemu, a jedynie jego przesunięcie na inną płaszczyznę. Zwolnienie organów stosujących prawo z obowiązku rozstrzygnięcia, czy dana ilość środków odurzajacych jest znaczna, na etapie prawnokarnej kwalifikacji danego czynu skutkowałoby bowiem koniecznością dokonania takich rozstrzygnięć na etapie wymierzania kary. Sądy i tak musiałby więc zmierzyć się z oceną ilości danego środka odurzającego, chociaż nadal nie miałaby do tego jasnych i ustawowych kryteriów.

dr Magdalena Kowalewska-Eukuć

Uniwersytet Szczecinski

mkowalewska@mec.univ.szczecin.pl

\section{EVALUATIVE CHARACTERISTICS OF ELEMENTS OF DRUG OFFENCES}

\section{Sum mary}

The article discusses the evaluative and vague characteristics used in the descriptions of the various types of offences in the context of the nullum crimen sine lege certa principle. The analysis of these characteristics was conducted on the grounds of the provisions of the Act on Preventing Drug Addiction in terms of the so-called allowable span and freedom of decision left for the authorities applying the law. The results of this analysis indicate that often enough the use by the legislature of the evaluative characteristics strains the principle of nullum crimen sine lege certa. The article also raises the issue of the possibility of proving in a criminal trial that the offender's conduct has fulfilled some specific characteristics of an offence. The subjectivity principle in criminal law in the context of evaluative characteristics has also been discussed. In conclusions, a possible solution to the problem of evaluative characteristics used in the provisions of the Act on Preventing Drug Addiction is proposed. 